\title{
A Way to Cultivate Postgraduates in Application and Practice
}

\author{
Wang Zhongsheng \\ School of Computer Science and Engineering \\ Xi'an Technological University \\ Xi'an, 710021, China \\ e-mail: 59483672@qq.com
}

\author{
Chong Jiao \\ School of Computer Science and Engineering \\ Xi'an Technological University \\ Xi'an, 710021, China \\ e-mail: 1342748406@qq.com
}

\begin{abstract}
With the reform and development of higher education, the number of graduate students has increased and the ability has been improved. Graduate students mainly learn theoretical knowledge and engaged in theoretical studies, but the development of economy needs a lot of graduate students with perfect skills and many English practice experience, so that current education pays attention to the ability of practice of students. On the basis of years of exploration, this paper puts forward a way of cultivate postgraduate in application and practice.
\end{abstract}

Keywords-Application and Practice; Graduate Education; Education Reform

\section{INTRODUCTION}

With the reform and development of higher education and the need of economy development, the graduate education in our country has big changes to solve the problem of talent shortage in economic development. The main changes include that the number of graduate students is increasing, the structure level is more diversified and the training mode is more flexible. However, in recent years, there are a lot of problems, such as the decline of graduate students' ability. How to ensure the quality of graduate students and a high level of personnel training is a serious problem as continuous enrollment expansion. Graduate students not only have a degree, but also have ability to solve some problems. This is a topic which needs for long-term exploration and research in our postgraduate training.

\section{THE PURPOSE OF POSTGRADUATE TRAINING}

In China, the goal of postgraduate education is to cultivate academic talents. Nevertheless, with the change of the economic situation and the needs of the market economy, thousands and thousands of applied research talents are needed in current economic construction. People could do pioneering work, and then form an innovative thinking and work style after a period of work. Graduate students do not pay attention to physical exercise and psychological quality training, and then it store up huge problems for the future, majority of scientific workers are in the state of sub-health.

School only pays attention to the cultivation of students' theoretical knowledge, rarely allows students to participate in creative activities and practical applications that is the problem of graduate education in our country. Fortunately, many graduate institutions have been aware of this problem and are actively turning into more effective cultivation models.

\section{CURRENT SITUATION OF POSTGRADUATES}

The survey shows that there are serious shortcomings in the current Chinese mode of postgraduate cultivation, which is essentially an "undergraduate" training mode. The main features of this model include:

- Curriculum is not reasonable, and the form of postgraduate teaching is similar to that of undergraduate teaching.

- Tutor's guidance is not enough.

- Students lack of scientific research.

- School management is too concentrated. 
In this mode of cultivation, students have a single thinking style and lack of innovation ability. Students blindly learn knowledge of the books, and then theoretical knowledge of graduates is insufficient and practical ability is weak, so they play a passive role in the employment.

Now, many well-known colleges and universities have to face an embarrassing situation that is undergraduate students are first-class, graduate students are second-class and doctoral students are third-class. What is the reason for this embarrassing situation? We should find the reasons from the graduate education.

1) Graduate matriculate quality. Graduate matriculate quality has a direct impact on the quality of graduate education. After the expansion of recruiting graduate students in high schools, the quality of postgraduate students is more and more important.

2) Academic atmosphere. The academic atmosphere is a concentrated expression of graduate student learning style and mental state. Students work hardly with the human spirit in a great atmosphere, but impetuous style of study would lead to a decline in students' learning quality.

3) Comprehensive quality. Comprehensive quality is the embodiment of person's knowledge, accomplishment, moral standards and ability. The reflection of the comprehensive quality of postgraduates is basically satisfied, and the quality of graduate students is fully affirmed. However, the graduate students have obvious shortcomings in the independent work and practical ability. With the maturity and development of market economy, new demands are set for the quality of postgraduate. It is necessary to have profound theoretical basis and operational ability for graduate students, and then complete the transition from students to workers during graduate study. Anyone has to meet the needs of the market, the purpose of educational reform is to reverse the situation that education is not suitable for the market. Graduate students work hard with the help of school and society to meet the requirements of society and the market.

\section{THE INVESTIGATION ON SOCIAL DEMAND}

On the whole, the overall development of the social talent market in the current society is relatively good, a lot of graduate students are still needed, and the country continue to expand graduate students to make up for the country's demand for high-technology workers. The country not only urgently needs more high-end theoretical talent, but also needs a lot of practical talents. Most of the graduate students do not meet the requirements, many enterprises think that the cost of recruiting graduate students is high and the practical application of students is too weak. Graduate students not only continue to learn theoretical knowledge, but also need more hands-on practice.

There has been changed in the demands of the talent market, state-owned enterprises need most of talents under the planned economy. With the gradual maturity of market economic system, the private enterprises are encouraged by the government, so that graduate students should constantly improve abilities to meet the requirements of enterprises. In fact, there is misunderstanding in today's talent demand, the employers blindly improve the employment standards, this method not only waste talent, but also increase the difficulty of employment. Some employers only focus on immediate interests, only employ candidates who have work experience, and do not consider reserve talents, and then resulting in a lot of graduates have employment pressure. This phenomenon cannot be changed, graduate students necessary to slowly adapt. So the quality of graduate students must continue to improve and then to meet the needs of personnel standards.

Now the employers think that the universal shortcoming for Chinese pupils is that students lack of the ability of practice, while their vision is high. Students only focus on exam results, do not pay attention to the improvement of practical ability. It seems that the knowledge what graduate students have learned during school is not used, and because the schedule is not reasonable, it takes students little time to study, but students spend a lot of time on unnecessary things. At the same time graduate tutor must be responsible for students, observe students' learning status and progress, of course, the most important thing is that students should have sufficient practical ability to meet the needs of the society. Graduate students must continue to improve their skills, make career planning first, and then continue to accomplish goals to improve their qualities and abilities of all aspects. 


\section{THE DIRECTION OF REFORM AND DEVELOPMENT}

Many colleges and universities have realized the existence of this problem, that there are serious shortcomings in the current Chinese mode of postgraduate cultivation, and try to reform education model. Through analysis and research, the following aspects can be improved:

1) Improve the comprehensive quality and ability with social practice. Through the social practice, the basic operation ability of postgraduate students, comprehensive application ability, social competence, and language ability are cultivated. Graduate students who only study textbooks do not have these abilities, could enrich social practice experience with social practice to improve their comprehensive quality and ability, and then students can quickly enter the working state after graduation.

Graduate students need to work in an enterprise for six months to a year, study and practice with technical developers. As communication and learning with technology developers, graduate students should know knowledge and technology what they lack as soon as possible, so that they could learn the theoretical knowledge according to their own weaknesses, and then students should apply the book knowledge to practical application to improve their comprehensive quality.

2) Enhance the practical application and operation of the paper. The treatise must come from the actual project, and include the approved data to improve the practicality of the thesis. Students only simply copy and paste other people's papers or books, which makes the content themselves. At present, graduate students cannot use their knowledge to solve practical problems. Graduate students often cannot clearly understand what they do, the contents of the paper are copied from books or other people's papers, and this paper does not have any use value. If the practical application and operation of the paper are enhanced, students could improve thinking ability and practical ability.

3) Students master a foreign language. At present, graduate students should pass the CET-6, application of foreign language proficiency can consult the literature and writing, and foreign-language magazine published an article with stronger literacy heard. Consulting foreign literature is a necessary method to study professional knowledge, and it has an important position in practical learning. And then some students do not pay attention to the learning of English, think that the professional courses are more important. Now employers often require students to pass the CET-4 and CET-6, English level of students is more important in some foreign companies. At present, our country is at the stage of development, $80 \%$ of the world's people communicate in English, and mastering English is very helpful for our future development.

The above is the current graduate students' direction of reform and development. Graduate students must improve abilities to work better.

\section{CONCLUSION}

The investigation shows that the current higher education model has shortcomings, it is necessary to reform to rapidly improve and develop the graduate education. And the reform of graduate training mode which needs in-depth study is a long and arduous task. Graduate training mode and training system must be reformed to adapt to the situation of country's economic development, which try to work out the best model for graduate development. The school should cultivate more capable talents for the country with this way, so that students who are welcomed by society can make a contribution to the development of science and education.

\section{ACKNOWLEDGMENT}

Fund support: Shaanxi Education Department Special Fund Project number: Shaanxi Education Finance[2013] 23

\section{REFERENCES}

[1] Wu Yiying, Chen Meng, Perplexity and Way-out: Reflections on the Reform of Graduate Cultivating System in China [J], Modern University Education, School of Economics and Management, Zhejiang Sci-Tech University, No.2, 2012.

[2] Liu Hong, The Cause of "Undergraduate" Cultivation Mode of Postgraduates in China [J], Jiangsu Higher Education, Central South University, No.5, 2013.

[3] Wang Ping, The Discussion of Problems and Reforming Ideas of Postgraduate Training Mode [J], Education for Chinese After-school, School of Economics and Management, Zhejiang Sci-Tech University, No.4, 2015.

[4] Zhang Jiliang, Zhang Junhua, Current Problems and Solutions in Postgraduate Education in China [J], Journal of Henan University of Technology (social science edition), Nanjing University Of Finance \& Economics Industrial Development Institute, No.2, 2016. 